
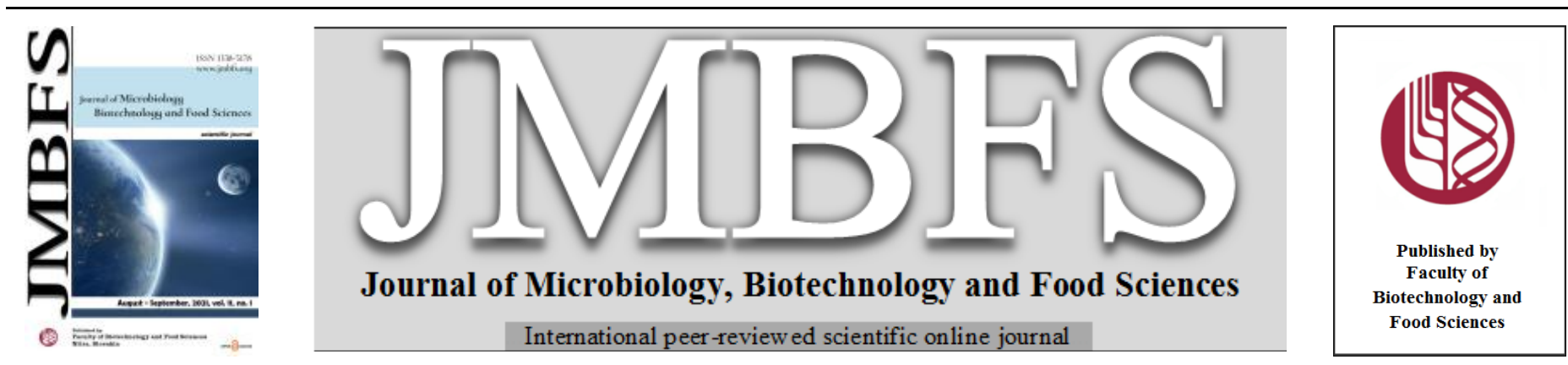

\title{
ANTIMICROBIAL ACTIVITY OF PIMENTA DIOICA (L.) Merr. LEAVES AND ITS SYNERGISTIC ACTIVITY WITH AMPICILLIN AGAINST ESBL PRODUCING CLINICAL ISOLATES
}

\author{
Meghana R. Gore, Darshana Raut, Aruna $K^{*}$ \\ Address(es): Dr. Aruna K., \\ Department of Microbiology, Wilson College, Girgaum Chowpatty, Mumbai 400007, Maharashtra.
}

*Corresponding author: arunasam2000@yahoo.co.in

https://doi.org/10.15414/jmbfs.653

\section{ARTICLE INFO}

Received 1. 8. 2018

Revised 10. 3. 2021

Accepted 10. 3. 2021

Published 1. 8. 2021

Regular article open $\partial_{\text {access }}$

\begin{abstract}
The intriguing discovery of antibiotics that led to innumerable accomplishments in the past is slowly losing its efficiency in the clinical society. The emergence of antibiotic-resistant pathogens, such as those which can hydrolyze $\beta$-lactam antibiotics with the help of enzymes such as Extended Spectrum $\beta$-lactamases (ESBLs) has created an urgent necessity to witness innovation in the current drug therapy, and develop new antimicrobial agents. Keeping the current clinical adversity in mind, the present study was carried out to investigate the antibacterial activity of Pimenta dioica (L.) Merr. extracts, prepared in various chemical solvents with the help of soxhlet apparatus, and its synergistic activity with ampicillin. The antibacterial activity of these extracts was verified against 45 ESBL producing bacteria. Our study revealed chloroform extract to exhibit maximum antibacterial activity evident with the zones of inhibition $(12-17 \mathrm{~mm})$ showed by agar diffusion method, and their observed Minimum Bactericidal Concentrations (MBC) in the range of 2-5 $\mathrm{mg} \cdot \mathrm{ml}^{-1}$. The MBC of ampicillin was found to decrease from $10 \mathrm{mg} \cdot \mathrm{ml}^{-1}$ to $300-500 \mu \mathrm{g} \cdot \mathrm{ml}^{-1}$ in presence of chloroform extracts of $P$. dioica (L.) Merr. leaves, indicating a synergistic activity between them. In addition, the TLC bioautography of chloroform extract was carried out using 2, 3, 5-Trimethyl tetrazolium chloride as a chromogen, and the separated bioactive components were analyzed with the help of GC-MS which showed eugenol as a major constituent. Moreover, the scanning electron microscope analysis confirmed a visible deformation in the cell membrane of $E$. coli treated with chloroform extracts of $P$. dioica (L.) Merr., indicating stress and cellular damage in presence of these extracts.
\end{abstract}

\section{INTRODUCTION}

The growing complications associated with Multiple Drug Resistant (MDR) strains of pathogens are clearly evident in the thousands of literature available online. The gradual exposure of pathogens to antibiotics, coupled with its indiscriminate use and consequent antibiotic selection pressure, has led to an enrichment of MDR strains not only in the hospitals but also in the general community (Selim, 2012). The progressive ineffectiveness of current antibiotics to treat major infectious diseases emanates from the long-term drug abuse by profit-seeking organizations (i.e., healthcare and pharmaceutical industries); and little awareness amongst the masses (Aruna and Mobashshera, 2012; Shriram et al., 2010). The complexity of this situation is further enhanced by the constantly evolving nature of drug resistance among pathogens, and the contemporaneous decline observed in drug discoveries in the last few decades (Ventola, 2015).

The emergence of Extended-Spectrum $\beta$-Lactamases (ESBLs) connotes one of the best examples in this situation. ESBLs are enzymes produced by MDR pathogens that confer a high degree of resistance to most of the commonly used $\beta$-lactam antibiotics including the advanced $3^{\text {rd }}$ generation cephalosporins viz., cefotaxime, ceftazidime, ceftriaxone etc. (Giske et al., 2008). The choice of treatment under such circumstances generally include administering a high dose of a suitable antibiotic from other classes, or the use of combination therapy However, they are commonly linked to severe side-effects; sometimes irreversibly damaging the liver and kidneys (Scarpignato et al., 2016). The host of other ill consequences of antibiotic over-use like drug dependence and correspondingly lowered immunity (Mohle et al., 2016), allergies (Garcia et al., 2012) etc., apart from the proven transformation of harmless bacteria to superbugs, elicits tapping alternative treatment protocols to confront these difficulties. In the past few decades, the attempts to safe clinical approaches have made scientist more keen towards other branches of medicine like Ayurveda, Unani, acupuncture, and phytotherapy to name a few (Chaudhury and Rafei, 2001).
The profound side-effects of high dose antibiotic therapies associated with effective treatment of infections are as much responsible for shifting our focus from the allopathic pharmacopeia, as it is for the safety and competency promised by the phytotherapeutic approaches. Phytotherapy is an indispensable branch of herbal medicine practiced exclusively in ancient times. Its fundamentals are deep-rooted in the undiscovered laws of nature that have greatly benefitted the humankind; among which, synergistic activity of biochemical compounds is one of the best understood unraveled phenomena. With the advent of antibiotics, it was believed that humans will revolutionize the clinical world and conquer over the health disasters, yet the traditional therapies have found its way back into the current era with promising solutions to the problem of antibiotic resistance. This can be apparently manifested by numerous research studies published previously by several authors (Tariq et al., 2014; Freitas et al., 2013).

Herbal medicines are a major source of the raw materials used alone and in combination with conventional antibiotics, and have shown promising activities against many pathogens (Belofsky et al., 2004; Beg et al., 2004). For instance, eugenol- a common constituent present in majority of the spices can induce cell lysis and leakage of protein and lipid content within 120min of exposure in Listeria monocytogenes, Streptococcus pyogenes, Proteus vulgaris and Escherichia coli (Oyedemi et al., 2009). It has also shown synergistic activity with several antibiotics (viz., penicillin, chloramphenicol, ampicillin, polymyxin $\mathrm{B}$, norfloxacin, tetracycline, rifampicin and vancomycin) against $E$. coli, Enterobacter aerogenes, P. vulgaris, Pseudomonas aeruginosa, Salmonella typhimurium as well as cariogenic and periodonto-pathogenic bacteria (Hemaiswarya and Doble, 2009; Moon et al., 2011).

The essential oils produced by plants during the process of secondary metabolism act as a concentrated mixture of bioactive components that can be used for medicinal purposes. The diverse mechanisms of these compounds can exhibit anti-bacterial, anti-fungal as well as anti-viral properties at the same time, as against most of the antibiotics that we use in general practice. The essential oils are also observed to negatively affect the pathogenicity of several organisms. Studies carried out on Staphylococcus aureus have shown that oregano oil can 
significantly reduce its lipase and coagulase activity (Carneiro de Barros $\boldsymbol{e t}$ al. 2009). In addition, eugenol oil reduces the production or activity of enterotoxin $A$ and $\mathrm{B}$, toxic shock syndrome toxin 1 and a-haemolysin in S. aureus (Qiu et al. 2010). Moreover, the carbonyl group on cinnamaldehydes may bind to proteins, thus inhibiting the function of bacterial amino acid decarboxylases (Wendakoon and Sakaguchi, 1993). The inhibition of ATPase activity due to disruption of cellular membrane, and blocking of efflux pumps is also reported (Bolla $\boldsymbol{e t}$ al. 2011; Di Pasqua et al., 2007). Hence, the identification, purification, and use of bioactive components from parts of medicinal plants may end our struggle to fight serious infections cost-effectively (Cheesman et al., 2017).

One such plant; and the basis of our current investigation, is Pimenta dioica (L.) Merr., commonly known as clove pepper, which is used as a spice. It is a sturdy perennial tree belonging to the family Myrtaceae. It possesses the characteristic flavor and aroma of clove, nutmeg, cinnamon and black pepper, all combined in this one spice, hence also named allspice (Kamble $\boldsymbol{e t}$ al., 2012). The traditiona literature, along with several recently published articles, verifies the use of $P$. dioica (L.) Merr. leaves and oil as an ailment against complications of the gastrointestinal tract, rheumatism, arthritis, stress and neuralgia. In some regions of India, it is also used as a means of relieving symptoms like pain, fever, indigestion and nausea (Khandelwal et al., 2012; Agrawal, 1997). The leaf and bark extracts of $P$. dioica (L.) Merr. have shown antimicrobial activity agains clinical isolates of Streptococcus mutans and $S$. aureus obtained from dental caries and burn exudates, respectively (Manasa et al., 2013; Al-Harbi et al., 2017). The essential oil extracted from this plant has also shown inhibitory effect on pathogens like Pseudomonas putida, E. coli, S. typhimurium, L monocytogenes and S. aureus (Al-Harbi et al., 2017; Oussalah et al., 2007) However, to our knowledge, no data is available on the efficacy of this plant against multi-drug resistant pathogens like ESBL producers.

Hence, considering the increasing antibiotic resistance among pathogens, the objective of our study was to investigate the efficacy of $P$. dioica (L.) Merr. leaf extract as a possible alternative source of medicine by exploring its antibacteria as well as synergistic activities against ESBL producing clinical isolates.

\section{MATERIAL AND METHODS}

\section{Plant material used in the study}

The leaves were collected from the $P$. dioica (L.) Merr. plant, maintained in a local garden, and authenticated by an expert botanist from Botany department, Wilson College, Mumbai, before use.

\section{Test organisms}

A total of 45 gram-negative ESBL producing pathological isolates, screened and characterized in our previous studies, were used in the current investigation (Tariq and Aruna, 2015; Tariq and Aruna, 2016). We selected 10 representative isolates each from the genera Klebsiella, Escherichia, Pseudomonas and Citrobacter, and 5 isolates from the genera Proteus for checking the antibacterial efficacy of $P$. dioica (L.) Merr. leaf extracts. All isolates were maintained on Luria-Bertani (LB) agar slants supplemented with $100 \mu \mathrm{g} . \mathrm{ml}^{-1}$ of ampicillin and stored at $4{ }^{\circ} \mathrm{C}$ until use in our laboratory.

\section{Preparation of the extracts}

The leaves of $P$. dioica (L.) Merr. plant were thoroughly cleaned with distilled water, dried in shade for 10 days, and powdered using a grinder before commencing the extraction procedure. The bioactive components were extracted from $15 \mathrm{~g}$ of powdered leaves in $200 \mathrm{ml}$ of chemical solvents viz., methanol, butanol, chloroform, petroleum ether and acetone for a duration of $8 \mathrm{~h}$ with the help of Soxhlet apparatus. The obtained extracts were concentrated by allowing the solvents to evaporate at Room Temperature (RT). The concentrates thus obtained, yielding $500 \mathrm{mg}-1.5 \mathrm{~g}$, were stored at $4^{\circ} \mathrm{C}$ until further use.

\section{Sterility testing of solvent extracts}

The sterility of the extracts was confirmed by checking for bacterial or funga growth after spot inoculating them on a sterile Nutrient Agar (NA) and Sabouraud's Agar (SAB) plate respectively (Hemaiswarya and Doble, 2009; Rao et al., 2010). The NA plates were incubated at $37^{\circ} \mathrm{C}$ and SAB plates at RT for an extended duration of 7 days to confirm the absence of contaminants.

Qualitative assay for determination of antibacterial activity of solvent extracts of $P$. dioica (L.) Merr. leaves

The antibacterial efficacy of each extract was analyzed qualitatively by agar well diffusion method. Sterile molten NA butt was seeded with $0.4 \mathrm{ml}$ of $24 \mathrm{~h}$ old test pathogens $\left(0.1 \mathrm{OD}_{540 \mathrm{~nm}}\right)$ and poured into sterile petri-plates. After solidification, wells were punched into the medium using a sterile cork-borer and inoculated with $50 \mu \mathrm{l}$ of solvent extracts. It was then allowed to diffuse through the wells during its incubation at $37^{\circ} \mathrm{C}$ for $24 \mathrm{~h}$, after which the resulting zones of inhibition were measured. The solvent extract showing the maximum zone of inhibition against test pathogens were selected for further study (Rao et al., 2010).

Determination of Minimum Bactericidal Concentration of $P$. dioica (L.) Merr. leaf extracts

The Minimum Bactericidal Concentration (MBC) of $P$. dioica (L.) Merr. leaf extracts was carried out with the help of agar dilution method using sterile Brain Heart Infusion (BHI) agar medium. Multiple plates of BHI agar were prepared by supplementing it with different concentrations of solvent extracts of $P$. dioica (L.) Merr. leaves (1-5 mg. $\mathrm{ml}^{-1}$ with an interval of $0.5 \mathrm{mg}^{-\mathrm{ml}^{-1}}$ ). The test pathogens were spot inoculated on these plates after solidification of media and incubated at $37^{\circ} \mathrm{C}$ for $24 \mathrm{~h}$. The lowest concentration of $P$. dioica (L.) Merr. leaf extract that inhibited the growth of pathogens was reported as MBC (Lorian, 1991).

\section{Determination of synergistic activity}

The agar dilution method was similarly used to determine the synergistic activity of solvent extracts of $P$. dioica (L.) Merr. leaves in presence of ampicillin. It was carried out by incorporating sub-lethal $(1 / 2 \mathrm{MBC})$ concentrations of $P$. dioica $(\mathrm{L}$.) Merr. leaf extracts into molten NA butt which were cooled to around $40^{\circ} \mathrm{C}$ along with 100-500 $\mu \mathrm{g} \cdot \mathrm{ml}^{-1}$ of ampicillin with an interval of $100 \mu \mathrm{g} \cdot \mathrm{ml}^{-1}$ (CLSI, 2006).

\section{Bioautography}

Thin layer chromatography (TLC) was carried out by spotting $25 \mu \mathrm{l}$ of $P$. dioica (L.) Merr. leaf extract on silica gel sheet $(2 \times 15 \mathrm{~cm})$ and immersing it in the solvent chamber. The solvent system was allowed to run until it reached around a $3 / 4^{\text {th }}$ length of the plate (Himanshu and Pradeep, 2012). After separation of components on silica gel, the sheets were dried, cut into two halves and placed in sterile petri-plates. It was then over-layed with sterile molten NA containing $24 \mathrm{~h}$ old culture of test pathogen and $0.03 \%$ of 2,3,5-Trimethyl tetrazolium chloride (TTC) which was used as the chromogen. The plates were incubated at $37^{\circ} \mathrm{C}$ for $24 \mathrm{~h}$, and the zones of inhibition were reported.

Table 1 Solvent systems used in Bioautography

\begin{tabular}{llc}
\hline Sr. no. & Solvent systems & Ratio \\
\hline 1. & Butanol: Acetic acid & $4: 1$ \\
\hline 2. & Toluene: Ethyl Acetate & $93: 7$ \\
\hline 3. & Toluene: Methanol: Acetone: Acetic acid & $14: 4: 1: 1$ \\
\hline 4. & Toluene:Acetic acid & $70: 30$ \\
\hline 5. & Chloroform: Ethyl acetate: Formic acid & $7.5: 6: 0.6$ \\
\hline 6. & Ethyl Acetate: Formic Acid: Acetic Acid & $100: 11: 27$ \\
\hline
\end{tabular}

\section{Gas Chromatography-Mass Spectrophotometry analysis}

The bioactive component from the chloroform extract of $P$. dioica (L.) Merr leaves was analyzed with the help of Gas Chromatography-Mass Spectrophotometry (GCMS). The GC-system was equipped with a capillary column of dimensions $30 \mathrm{~m}$ X $0.25 \mathrm{~mm}$ X $0.25 \mu \mathrm{m}$. The program used for GC oven temperature was $5 \mathrm{~min}$ isothermal at $300^{\circ} \mathrm{C}$, followed by $90^{\circ}-280^{\circ} \mathrm{C}$ at a rate of $6^{\circ} \mathrm{C} / \mathrm{min}$, then held at $280^{\circ} \mathrm{C}$ for $5 \mathrm{~min}$. The injection port temperature was $240^{\circ} \mathrm{C}$. Along with that a Joel, AccuTOF GCV MS system, with a time of fligh analyzer, was used (Tariq et al., 2014).

In addition, the active components exhibiting anti-bacterial activity, identified qualitatively with the help of above mentioned bioautography technique was also analyzed by GCMS. In this case, the separated components were scraped from silica plates with the help of sterile scalpel and dissolved in chloroform which was used as a sample for GCMS

Both analyses were carried out at IIT Bombay, Mumbai 400076 and the compounds in the crude extract were identified by comparing their retention indices (RI) and mass spectra fragmentation with those in the stored library available with IIT, Bombay.

\section{Scanning Electron Microscopy}

The effect of the chloroform extract of $P$. dioica (L.) Merr., on the cell membrane of pathogenic E. coli, was investigated by using Scanning Electron Microscopy (SEM). The $E$. coli cells treated with sub-lethal concentrations of the chloroform extract of $P$. dioica (L.) Merr. leaves were considered as a test sample and untreated cells were used as a control sample in the current study. After $24 \mathrm{~h}$ incubation, the test and control cells were suspended in $1 \mathrm{ml}$ of Phosphate buffered saline and fixed onto clean grease free cover-slips (Kim et al., 2015) They were allowed to dry and then analyzed by SEM at SAIF, IIT Powai. 


\section{Statistical analysis}

All the experiments were performed in triplicates and reported as mean \pm Standard Deviation (SD).

\section{RESULTS AND DISCUSSION}

\section{Sterility testing of solvent extracts}

The extracts of $P$. dioica (L.) Merr. leaves showed the absence of bacterial and fungal contaminants even after 7 days of incubation. The extended incubation time confirmed the absence of slow-growing contaminants and stressed cells that may have survived the processing of solvent extracts.

\section{Qualitative assay for determination of antibacterial activity of solvent extracts of $P$. dioica (L.) Merr. leaves}

Figure 1 represents the antibacterial activities of chloroform and petroleum ether extracts of $P$. dioica (L.) Merr. leaves carried out by agar well diffusion method. It showed zones of inhibition in the range of 12-17 $\mathrm{mm}$. The acetone and methanol extracts did not show any activity against the test pathogens. Consequently, no further studies were carried out using these extracts. The solvent controls, in our study, did not show any zone of inhibition against test pathogens except for butanol. Hence, further studies with butanol extract were also discontinued.

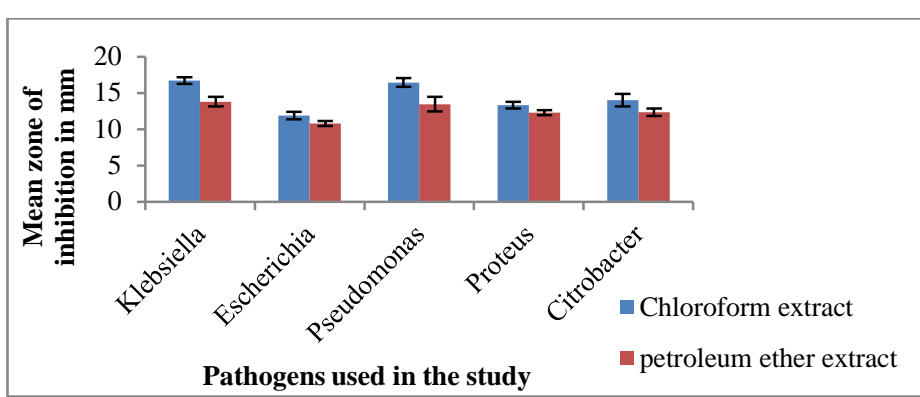

Figure 1 Antibacterial activity of chloroform and petroleum ether extract of $P$ dioica (L.) Merr. leaves against ESBL producers

Other researchers have also reported the effective antibacterial activity of $P$. dioica (L.) Merr. extracts against Pseudomonas aeruginosa, Escherichia coli, Listeria monocytogenes, Salmonella typhimurium and Staphylococcus aureus (Marzouk et al., 2007; Oussalah et al., 2006). A similar study carried out with allspice oil reported zones of inhibition in the range of 22-44 mm agains Candida species. Khandelwal et al. (2012) reported significant antibacteria activity of methanol extract of $P$. dioica (L.) Merr. leaves when compared to acetone and an aqueous solvent, against test isolates of $E$. coli, Bacillus cereus, $S$. typhimurium, and $S$. aureus, carried out in their study. The zones of inhibition of methanol extract were observed in the range of 11-13 mm. Another study carried out using alcohol and hexane extracts of $P$. dioica leaves showed zones of inhibition of $32.1 \pm 0.26 \mathrm{~mm}$ for Bacillus megaterium and $20.3 \pm 0.16 \mathrm{~mm}$ for Pseudomonas fluorescens (Boyd and Benkeblia, 2014). A similar study was carried out to study the efficacy of the leaf and bark extracts of $P$. dioica (L.) Merr. against clinical isolates of $S$. aureus and $S$. mutans isolated from burn and dental caries patients respectively. They reported zones of inhibition in the range of 14-21 mm against the test pathogens (Asha et al., 2013)

\section{Determination of MBC by Agar dilution method}

The ineffectiveness of acetone and methanol extracts, and the antibacteria activities of chloroform and petroleum ether extracts, of $P$. dioica (L.) Merr against the test pathogens, were further confirmed by determination of it MBCs. Table 2 represents the mean MBC values of the chloroform extract of $P$. dioica (L.) Merr. carried out by agar dilution method. It was found to be in the range of 2-5 mg. $\mathrm{ml}^{-1}$. Other solvent extracts of $P$. dioica (L.) Merr. leaves showed very high MBC as compared to that of chloroform extract. As a result, further studies were carried out using only chloroform extracts of $P$. dioica (L.) Merr. leaves.

\section{Table 2 MBC of chloroform extract against ESBL pathogens}

\begin{tabular}{ccc} 
Test organisms & No. of isolates & $\begin{array}{c}\text { Mean MBC of chloroform extract } \\
\text { of } \boldsymbol{P} \text {. dioica }(\mathbf{L} .) \text { Merr. }\end{array}$ \\
\hline $\begin{array}{c}\text { Klebsiella } \\
\text { pneumoniae }\end{array}$ & 10 & $3.5 \mathrm{mg} \cdot \mathrm{ml}^{-1}$ \\
\hline Escherichia coli & 10 & $2 \mathrm{mg} \cdot \mathrm{ml}^{-1}$ \\
\hline Pseudomonas spp. & 10 & $4.5 \mathrm{mg} \cdot \mathrm{ml}^{-1}$ \\
\hline Proteus spp. & 05 & $3.5 \mathrm{mg} \cdot \mathrm{ml}^{-1}$ \\
\hline Citrobacter spp. & 10 & $5 \mathrm{mg} \cdot \mathrm{ml}^{-1}$ \\
\hline
\end{tabular}

Kang et al. (2011) studied the MBC of methanol extracts of 8 different medicinal herbs that are native to South Korea. The study was carried out against 15 standard ATCC and CDC strains and their reported MBC ranged between of 1.22-5000 $\mu \mathrm{g} \cdot \mathrm{ml}^{-1}$. A similar study reported MBC of essential oils extracted from $P$. dioica (L.) Merr. leaves against $S$. aureus and B. cereus to be $2.5 \mathrm{mg} . \mathrm{ml}^{-1}$ and $20 \mathrm{mg}^{-\mathrm{ml}^{-1}}$ respectively (Vazquez et $\boldsymbol{a l}$., 2013). The extensive variations observed in the zones of inhibition and MBC values in several studies including ours can be attributed to several underlying factors which cannot be controlled by researchers in certain cases. For example, it is a well-known fact that growth conditions of plants severely affect its biochemical composition. Hence, the same plant collected from different areas may give rise to variations in the study. Other factors that may contribute to variations include the type of solvent used for extraction of bioactive components, extraction protocol, type of media and inoculum size among others.

\section{Determination of synergistic activity}

Table 3 provides an overview of the synergistic activity observed between the sub-lethal concentration of chloroform extract of $P$. dioica (L.) Merr. leaves and ampicillin. An impressive reduction was observed in the MBC value of ampicillin i.e., from $10 \mathrm{mg} \cdot \mathrm{ml}^{-1}$ to $300-500 \mu \mathrm{g} \cdot \mathrm{ml}^{-1}$ when used in combination with chloroform extracts of $P$. dioica (L.) Merr.

Table 3 Synergistic activity of Chloroform extract of $P$. dioica (L.) Merr leaves and ampicillin

\begin{tabular}{|c|c|c|c|c|}
\hline $\begin{array}{l}\text { Test } \\
\text { Pathogens }\end{array}$ & $\begin{array}{c}\text { MBC of } \\
\text { Ampicillin }\end{array}$ & $\begin{array}{l}\text { Mean MBC of } P \text {. dioica }(\mathbf{L} .) \\
\text { Merr. Extract }\left(\mathbf{m g} \mathbf{m l}^{-1}\right)\end{array}$ & $\begin{array}{l}\text { Sub-lethal concentration of } \\
\text { P. dioica (L.) Merr. extract } \\
\text { used (mg.ml }{ }^{-1} \text { ) }\end{array}$ & $\begin{array}{l}\text { Synergy observed - MBC of } \\
\text { ampicillin in presence of } P \text {. dioica } \\
\text { (L.) Merr. extract }\left(\mu \mathrm{g} \cdot \mathrm{ml}^{-1}\right)\end{array}$ \\
\hline E. coli $(10)$ & \multirow{5}{*}{$\begin{array}{l}\text { More than } \\
10 \mathrm{mg} / \mathrm{ml}\end{array}$} & 2 & 1.5 & 500 \\
\hline K. pneumoniae (10) & & 3.5 & 2.5 & 300 \\
\hline Citrobacter spp. (10) & & 5 & 4 & 300 \\
\hline Proteus spp. (5) & & 3.5 & 2.5 & 300 \\
\hline Pseudomonas spp. (10) & & 4.5 & 3 & 500 \\
\hline
\end{tabular}

Our previous study carried out with ethanolic ajwain extract also showed similar results (Tariq et al., 2014). Similar findings have also been reported by Voukeng et al. (2012), where a synergistic effect was observed between 11 different Cameroon spices and erythromycin in $56.25 \%$ of the tested bacteria. Another study by Noumedem et al. (2013) reported synergistic activities of Piper nigrum and Telfairia occidentalis in presence of 7 different antibiotics used in their study. Since, the pathogens have developed resistance to most of the existing antibiotics, discovering a new antibiotic is probably not an effective solution to the problem. Instead, the modification of existing therapies, although challenging, may be more practical and productive in terms of treatment options. To this effect, our current study holds immense value in the screening of valuable medicinal plant like $P$. dioica (L.) Merr., which is not only antibacterial in nature but also shows potential in reversing the already developed resistance to common antibiotics like ampicillin.

\section{Bioautography}

In our study, two TLC plates were run simultaneously, out of which one of them was placed in a petri-plate and over-layed with NA medium containing test isolate and TTC. The separated constituent showing antibacterial activity, after the incubation period, was scraped from the second plate and analyzed using GCMS. Among the six solvent systems used, Toluene: Ethyl acetate showed a maximum zone of inhibition around the isolated component. Figure 2 represents the TLC of chloroform extract which was developed in Toluene: Ethyl acetate solvent system. Figure 3 represents the TLC plate used to carry out bioautography. 


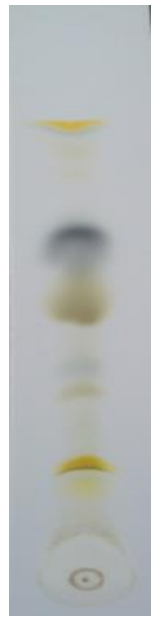

Figure 2 TLC of chloroform extract of $P$. dioica (L.) Merr. developed in Toluene: Ethyl acetate solvent system

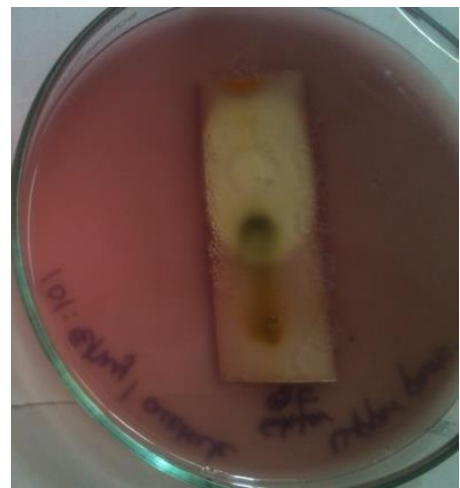

Figure 3 Bioautography of the chloroform extract of $P$. dioica (L.) Merr. leaves

Bioautography is a simple and effective method that can be applied to studies related to natural compounds since the antibacterial activity of all separated constituents can be qualitatively determined at once. It is for this reason that bioautography method is preferred by many researchers. A study carried out by Vazquez et al., (2013) reported two separated fractions of $P$. dioica (L.) Merr showing antibacterial activity. In addition, they also carried out bioautography using extracts of $M$. arboreus, B. crassifolia, and P. guajava. However, antibacterial activity was observed only from the fractions of $P$. dioica and $P$. guajava. Similarly, another study reported 4 different fractions obtained from the methanolic extract of Ricinus communis to show antibacterial activity against $P$. aeruginosa and K. pneumoniae (Sandam and Ponamma, 2015).

\section{GC-MS analysis}

The chromatogram showing Retention Time $\left(\mathrm{RT}_{\mathrm{m}}\right)$ of several constituents identified with the help of GC-MS analysis of a crude extract of $P$. dioica (L.) Merr. leaves, obtained in chloroform are shown in figure 4. It showed 7 distinct peaks and the highest peak observed at $\mathrm{RT}_{\mathrm{m}} 18.1$ mins was identified as eugenol, making it a major constituent of chloroform extract. In addition, 2-allylphenol, dibutyl phthalate, and crocetane were found to be present in a significant concentration as compared to other constituents (Table 4). Figures 5 represents the chromatogram of the separated band of chloroform extract on TLC plate showing antibacterial activity, determined by bioautography. The retention times and their corresponding constituents of crude chloroform extract and TLC separated bioactive constituents identified by GC-MS analysis in our study is listed in Table 4.

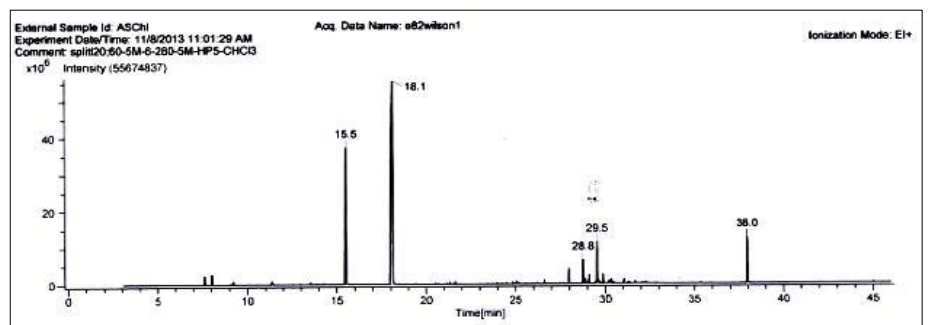

Figure 4 Chromatogram of chloroform extract of $P$. dioica (L.) Merr. leaves

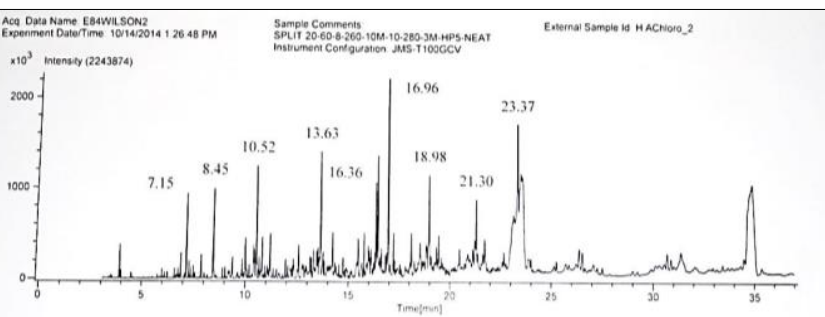

Figure 5 Chromatogram of separated band on TLC plate used in bioautography

Table 4 Identified constituents from chloroform extracts of $P$. dioica (L.) Merr. leaves using GC-MS analysis

\begin{tabular}{lccc}
\hline $\begin{array}{l}\text { Sr. } \\
\text { no. }\end{array}$ & Sample & $\begin{array}{c}\text { Retention time } \\
\text { (mins) }\end{array}$ & Compounds \\
\hline 1. & Chloroform extract & 7.6 & Caprylene \\
& & 8.0 & Beta-Myrcene \\
& 15.5 & 2-allylphenol \\
& 18.1 & m-Eugenol \\
& 28.0 & Phthalic acid \\
& 29.4 & Crocetane \\
& 29.5 & Dibutyl phthalate \\
& 38 & 1,2 benzene dicarboxylic \\
& & acid disoctyl ester \\
\hline 2. & 7.15 & Dodecane 2,6,11trimethyl \\
& Separated band on & 8.45 & Eugenol, Iso-Eugenol \\
& TLC plate used for & 10.52 & Dodecane, 2, 6, 11- \\
bioautography & 13.63 & trimethyl \\
& 16.96 & Tridecanol,2-ethyl-2- \\
& 23.37 & methyl \\
& & Hexadecane, 1-iodo \\
& & (i) 1,2-Benzene di- \\
& & carboxylic acid, diisooctyl \\
& & ester \\
& & (ii) 1,2 -Benzene di- \\
& & carboxylic acid, mono(2- \\
& & ethylhexyl) ester \\
& & Dibutyl phthalate \\
\hline
\end{tabular}

In our study, Eugenol was found to be the major constituent of the chloroform extract of P. dioica (L.) Merr. leaves, however, the separated band on TLC plate exhibiting antibacterial activity, showed a lower concentration of eugenol comparatively. Although the most probable anti-bacterial activity of the abovementioned compounds may be attributed to the most abundant constituent in the extract, it cannot be claimed with absolute certainty. In certain cases, the bioactivity of constituents present in smaller concentration may attenuate the significance of other constituents present in higher concentrations. The antibacterial activity of eugenol is reported in several studies. A recent review published by Marchese $\boldsymbol{e t}$ al. (2017) describes the extensive reports associating the antioxidant and anti-inflammatory activities of eugenol to health benefits. In addition, several published records of the efficacy of eugenol against antibiotic sensitive as well as resistant pathogens are highlighted in their study. Another study carried out to investigate the mechanism of action of eugenol oil indicated that it is very efficient in inactivating $S$. typhi within 60 mins post exposure. They indicated that the chemo-attractant and bactericidal properties of eugenol can work more efficiently when given in vivo. In their study, eugenol was found to increase the permeability of the cell membrane, which was confirmed by the crystal violet assay (Devi et al., 2013). Other phenolic compounds and organic acids identified in table 4 are also proven for its antibacterial activities in several previously published studies (Alves et al., 2013; Maldonado et al., 2011).

\section{Scanning Electron Microscopy}

The effect of the chloroform extract of $P$. dioica (L.) Merr. leaves on ESBL producing $E$. coli was investigated by SEM analysis. The E. coli cells treated with (test) and without (control) P. dioica (L.) Merr. extracts are shown in figures $6 \mathrm{a}$ and $\mathrm{b}$ respectively. The test sample shows distortion of shape and swelling in structure. In addition, the prominent white outline evident in the control sample also appears to be broken and uneven when observed in test samples. These results clearly indicate cell wall damage and stress induced in the ESBL producing $E$. coli test cells used in our study, hence confirming the potency of chloroform extract of $P$. dioica $(\mathrm{L}$.) Merr. leaves. 


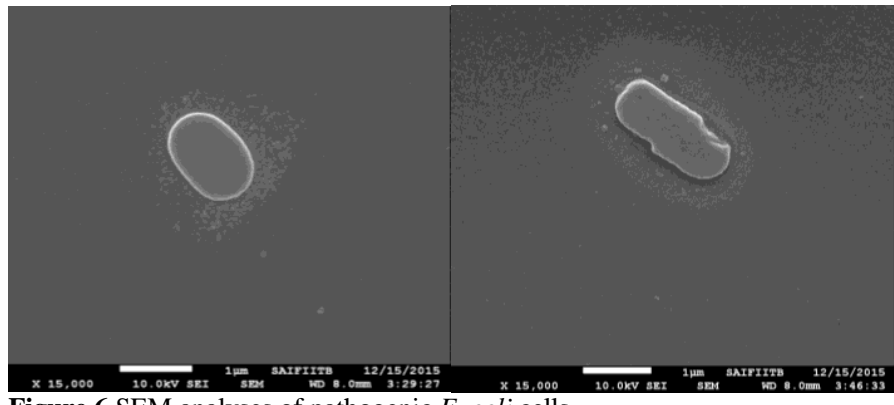

Figure 6 SEM analyses of pathogenic E. coli cells

A similar study carried out by Kamonwannasit et al. (2013) reported swelling and distortion of bacterial cells on treatment with extracts of Aquilaria crassna and inhibition of bacterial biofilm formation. In addition, a rupture in bacteria cell wall was observed after treatment of bacterial isolates with the extract for $24 \mathrm{~h}$. Both results in their study was confirmed by SEM analysis. Another study by Kaya et al. (2008) reported shrinking of bacterial cells and cell wall degradation of bacterial cells on treatment with Ocimum basilicum extracts.

\section{CONCLUSION}

The present study confirms antibacterial activitiy of $P$. dioica (L.) Merr. leaf extracts and its synergistic activity with ampicillin. The distortion and cellular damage caused by $P$. dioica (L.) Merr. leaf extract on bacterial cells are also evident by SEM analysis carried out in our study. Moreover, the organic acids and phenolic compounds identified by GC-MS along with eugenol can be the basis of future studies aimed at in-depth analysis of activities of these compounds. All these findings consistently indicate the potential of $P$. dioica $(\mathrm{L}$.) Merr. leaf extracts to be potential chemotherapeutic agents for the treatment of infections caused by drug-resistant pathogens.

Acknowledgments: The current study was funded by UGC as a minor research project [reference no. 47-587/13 (WRO)].

\section{REFERENCES}

Agrawal, V. S. (1997). Drug plants of India (1st edition Vol. II). Kalayani publisher: New Delhi.

Alves, M. J., Ferreira, I. C., Froufe, H. J., Abreu, R. M., Martins, A., \& Pintado, M. (2013). Antimicrobial activity of phenolic compounds identified in wild mushrooms, SAR analysis and docking studies. Journal of Applied Microbiology, 115(2), 346-357. https://doi.org/10.1111/jam.12196

Aruna, K., \& Mobashshera, T. (2012). Prevalence of extended spectrum betalactamase production among uropathogens in south Mumbai and its antibiogram pattern. EXCLI Journal, 11, 363-372.

Asha, M. M., Chaithra, M., Yashoda, K., Vivek, M. N., \& Prashith, K. T. R. (2013). Antibacterial activity of leaf and bark extracts of Pimenta dioica (linn.) Merill against clinical isolates of Staphylococcus aureus and Streptococcus mutans. World Journal of Pharmacy and Pharmaceutical sciences, 2(5), 32073215.

Beg, A. Z., \& Ahmad I. (2004). Effect of Plumbago zeylanica extract and certain curing agents on multidrug resistant bacteria of clinical origin. World Journal of $\begin{array}{lll}\text { Microbiology and Biotechnology, 16(8-9), } & 841-844 .\end{array}$ https://doi.org/10.1023/A:1008991724288

Belofsky, G., Percivill, D., Lebis, K., Tegos, G. P., \& Ekart, J. (2004). Phenolic metabolites of Dalea versicolor that enhance antibiotic activity against mode pathogenic bacteria. Journal of Natural Products, 67(3), 481-484. https://doi.org/10.1021/np030409c

Bolla, J. M., Alibert-Franco, S., Handzlik, J., Chevalier, J., Mahamoud, A., Boyer, G., Kieć-Kononowicz, K., \& Pagès, J. M. (2011). Strategies for bypassing the membrane barrier in multidrug resistant Gram-negative bacteria. FEBS Letters, 585(11), 1682-1690. https://doi.org/10.1016/j.febslet.2011.04.054

Boyd, F. A. H., \& Benkeblia, N. (2014). In vitro evaluation of antimicrobia activity of crude extracts of Pimenta dioica L. (MERR.). Acta horticulturae, 1047(1047), 199-205. https://doi.org/10.17660/ActaHortic.2014.1047.24

Carneiro de Barros, J., Lucia da Conceicao, M., Gomes Neto, N. J., Vieira da Costa, A. C., Pinto Siqueira, J. J., Diniz Basílio, I. J., \& Leite de Souza, E. (2009). Interference of Origanum vulgare L. essential oil on the growth and some physiological characteristics of Staphylococcus aureus strains isolated from foods. Food Science and Technology, 42(6), 1139-1143. https://doi.org/10.1016/j.lwt.2009.01.010

Chaudhury, R. R., \& Rafei, U. M. (2001). Traditional Medicine in Asia. World Health Organization, SEARO Regional Publications, New Delhi, India.

Cheesman, M. J., Ilanko, A., Blonk, B., \& Cock, I. E. (2017). Developing New Antimicrobial Therapies: Are Synergistic Combinations of Plant Extracts/Compounds with Conventional Antibiotics the Solution?
Pharmacognosy Reviews,

11(22)

$57-72$

http://doi.org/10.4103/phrev.phrev $21 \quad 17$

Clinical and Laboratory Standards Institute. Methods for dilution antimicrobial susceptibility tests for bacteria that grow aerobically-seventh edition: approved standard M07-A7. 2006. CLSI, Wayne, PA.

Devi, K. P., Sakthivel, R., Nisha, S. A., Suganthy, N., \& Pandian, S. K. (2013) Eugenol alters the integrity of cell membrane and acts against the nosocomia pathogen Proteus mirabilis. Archives of Pharmacal Research, 36(3), 282-292. https://doi.org/10.1007/s12272-013-0028-3

Di Pasqua, R., Betts, G., Hoskins, N., Edwards, M., Ercolini, D., \& Mauriello, G. (2007). Membrane toxicity of antimicrobial compounds from essential oils Journal of agricultural and Food Chemistry, 55(12), 4863-4870. http://doi.org/10.1021/jf0636465

Freitas, E., Aires, A., Rosa, E. A., \& Saavedra, M. J. (2013), Antibacterial activity and synergistic effect between watercress extracts, 2-phenylethyl isothiocyanate and antibiotics against 11 isolates of Escherichia coli from clinica and animal source. Letters in Applied Microbiology, 57(4), 266-273. https://doi.org/10.1111/lam.12105

Garcia, N. I., Barasona, M. J., Algaba, M. A., Moreno, A. C., \& Guerra, P. F. (2012). Diagnosis of patients with immediate hypersensitivity to beta-lactams using retest. Journal of Investigational Allergology and Clinical Immunology, 22(1), 41-47.

Giske, C. G., Monnet, D. L., Cars, O., Carmeli, Y., \& on behalf of ReAct-Action on Antibiotic Resistance. (2008). Clinical and Economic Impact of Common Multidrug-Resistant Gram-Negative Bacilli. Antimicrobial Agents and Chemotherapy, 52(3), 813-821. http://doi.org/10.1128/AAC.01169-07

Hemaiswarya, S., \& Doble, M. (2009). Synergistic interaction of eugenol with antibiotics against gram-negative bacteria. Phytomedicine, 16(11), 997-1005. https://doi.org/10.1016/j.phymed.2009.04.006

Himanshu, M., \& Pradeep P. (2012). Screening of Antimicrobials of some Medicinal Plants by TLC Bioautography. International Journal of Pharmaceutical Innovations, 2(1), 60-71.

Kamble, V. A. (2012). In Vitro anti-candidal activity of Pimenta dioica (allspices) essential oil against clinical isolates of Candida albicans and nonalbicans Candida. International Journal of Life science and Pharma Research, 2(3), 150-159.

Kamonwannasit, S., Nantapong, N., Kumkrai, P., Luecha, P., Kupittayanant, S., \& Chudapongse, N. (2013). Antibacterial activity of Aquilaria crassna leaf extract against Staphylococcus epidermidis by disruption of cell wall. Annals of Clinical Microbiology and Antimicrobials, 12, 20. https://doi.org/10.1186/1476$\underline{0711-12-20}$

Kang, C. G., Hah, D. S., Kim, C. H., Kim, Y. H., Kim, E., \& Kim, J. S. (2011) Evaluation of Antimicrobial Activity of the Methanol Extracts from 8 Traditional Medicinal Plants. Toxicological Research,27(1), 31-36. http://doi.org/10.5487/TR.2011.27.1.031

Kaya, I., Yigit, N., \& Benli, M. (2008). Antimicrobial Activity of Various Extracts of Ocimum Basilicum L. and Observation of the Inhibition Effect on Bacterial Cells by Use of Scanning Electron Microscopy. African Journal of Traditional, Complementary and Alternative Medicines, 5(4), 363-369. https://doi.org/10.4314/ajtcam.v5i4.31291

Khandelwal, P., Upendra, R. S., Raftaniamiri, Z., \& Ramachandra G. G. (2012) Assessment of biotherapeutic potential of Pimenta dioica (allspice) leaf extract International Journal of Pharmaceutical Science and Research, 3(9), 3379-3383. Kim, S., Lee, H., Lee, S., Yoon, Y., \& Choi, K.H. (2015). Antimicrobial Action of Oleanolic Acid on Listeria monocytogenes, Enterococcus faecium, and Enterococcus faecalis. PLoS ONE, 10(3), e0118800. http://doi.org/10.1371/journal.pone.0118800

Lorian, V. (1991). Antibiotics in laboratory medicine. Baltimore: The Williams and Wilkins Company.

Maldonado, A. F., Schieber, A., \& Gänzle, M. G. (2011). Structure-function relationships of the antibacterial activity of phenolic acids and their metabolism by lactic acid bacteria. Journal of Applied Microbiology. 111(5), 1176-1184. https://doi.org/10.1111/j.1365-2672.2011.05141.x

Marchese, A., Barbieri, R., Coppo, E., Orhan, I. E., Daglia, M., Nabavi, S. F. Izadi, M., Abdollahi, M., Nabavi, S. M., \& Ajami, M. (2017). Antimicrobial activity of eugenol and essential oils containing eugenol: A mechanistic viewpoint. Critical Reviews in Microbiology, 43(6), 668-689. https://doi.org/10.1080/1040841x.2017.1295225

Marzouk, M. S., Moharram, F. A., Mohamed, M. A., Gamal-Eldeen, A. M., \& Aboutabl, E. A. (2007). Anticancer and Antioxidant Tannins from Pimenta dioica Leaves. Zeitschrift für Naturforschung $C, \quad 62(\mathrm{c}), \quad 526-536$. https://doi.org/10.1515/znc-2007-7-811

Mohle, L., Mattei, D., Heimesaat, M. M., Bereswill, S., Fischer, A., Alutis, M., French, T., Hambardzumyan, D., Matzinger, P., Dunay, I. R., \& Wolf, S. A

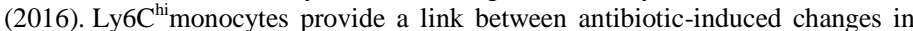
gut microbiota and adult hippocampal neurogenesis. Cell Reports, 15(9), 1945 1956. http://dx.doi.org/10.1016/j.celrep.2016.04.074 
Moon, S. E., Kim, H. Y., \& Cha, J. D. (2011). Synergistic effect between clove oil and its major compounds and antibiotics against oral bacteria. Archives of oral Biology, 56(9), 907-916. http://doi.org/10.1016/j.archoralbio.2011.02.005

Noumedem, J. A., Mihasan, M., Kuiate, J. R., Stefan, M., Cojocaru, D., Dzoyem, J. P., \& Kuete, V. (2013). In Vitro antibacterial and antibiotic-potentiation activities of four edible plants against multidrug-resistant gram-negative species. BMC Complementary and Alternative Medicine, 13, 190 http://doi.org/10.1186/1472-6882-13-190

Oussualah, M., Caillet, S., Saucier, L., \& Lacroix, M. (2006). Antimicrobial effects of selected plant essential oils on the growth of Pseudomonas putida strain isolated from meat. Meat Science, 73(2), 236-244. https://doi.org/10.1016/j.meatsci.2005.11.019

Oyedemi, S. O., Okoh, A. I., Mabinya, L. V., Pirochenva, G., \& Afolayan, A. J. (2009). The proposed mechanism of bactericidal action of eugenol, $\alpha$-terpineol and $\gamma$-terpinene against Listeria monocytogenes, Streptococcus pyogenes, Proteus vulgaris and Escherichia coli. African Journal of Biotechnology, 8, 1280- 1286. Qiu, J., Feng, H., Lu, J., Xiang, H., Wang, D., Dong, J., Wang, J., Wang, X., Liu, J., \& Deng, X. (2010). Eugenol reduces the expression of virulence-related exoproteins in Staphylococcus aureus. Applied and Environmental Microbiology, 76(17), 5846-5851. http://doi.org/10.1128/AEM.00704-10

Rao, P. S., Sheth, N. R., Jayaveera, K. N., \& Rao, S. K. (2010). Pharmacognostic standardisation of the leaves of Pimenta dioica. International Journal of Pharmaceutical Sciences and Research, 1(9), 110-115.

Sandam, N., \& Ponamma, S. U. (2015). TLC-bioautography guided screening of the methanolic extract of Ricinus communis. International Journal of Pharma and Bio Sciences, 6(1), 427-432.

Scarpignato, C., Gatta, L., Zullo, A., Blandizzi, C., for the SIF-AIGO-FIMMG Group, on behalf of the Italian Society of Pharmacology, the Italian Association of Hospital Gastroenterologists, \& the Italian Federation of General Practitioners (2016). Effective and safe proton pump inhibitor therapy in acid-related diseases - A position paper addressing benefits and potential harms of acid suppression. BMC Medicine, 14, 179. http://doi.org/10.1186/s12916-016-0718-z

Selim, S. A. (2012). Antimicrobial, antiplasmid and cytotoxicity potentials of marine algae Halimeda opuntia and Sarconema filiforme collected from Red Sea Coast. World Academy of Science, Engineering and Technology, 61, 1154-1159.

Shriram, V., Jahagirdar, S., Latha, C., Kumar, V., Dhakephalkar, P., Rojatkar, S., \& Shitole, M. G. (2010). Antibacterial and antiplasmid activities of Helictere sisora L. Indian Journal of Medical Research, 132, 94-99.

Tariq, M., \& Aruna, K. (2015). Phenotypic and Molecular characterization of MBL genes among uropathogens isolated in Mumbai city. British Microbiology Research Journal, 5(4), 368-383. https://doi.org/10.9734/bmrj/2015/13762

Tariq, M., \& Aruna, K. (2016). Molecular detection of co-production of ESBL AmpC and Integrons among uropathogens in a study from Mumbai. European Journal of Biomedical and Pharmaceutical Sciences, 3(4), 377-391.

Tariq, M., More, M., \& Aruna, K. (2014). Antibacterial and synergistic activity of ajwain (Trachyspermum ammi) extract on ESBL and MBL producing uropathogens. International Journal of Pharmacy and Pharmaceutical sciences, 6(6), 278-284

Vazquez, C, Daniel, A., Espinosa, M., Judith, Centurion, H., Dora, Velazquez, M., Jose, R., Borges, A. R., \& Caceres, F. M. (2013). Antimicrobial activity and chemical composition of the essential oils of Malvaviscus arboreus Cav, Pimenta dioica (L.) Merr., Byrsonima crassifolia (L.) Kunth and Psidium guajava L. Tropical and Subtropical Agroecosystems, 16(3), 505-513.

Ventola, C. L. (2015). The Antibiotic Resistance Crisis: Part 1: Causes and Threats. Pharmacy and Therapeutics, 40(4), 277-283.

Voukeng, I. K., Kuete, V., Dzoyem, J. P., Fankam, A. G., Noumedem, J. A. K., Kuiate, J. R., \& Pages, J.M. (2012). Antibacterial and antibiotic-potentiation activities of the methanol extract of some cameroonian spices against Gramnegative multi-drug resistant phenotypes. BMC Research Notes, 5, 299 http://doi.org/10.1186/1756-0500-5-299

Wendakoon, C. N., \& Sakaguchi, M. (1993). Combined effect of sodium chloride and clove on growth and biogenic amine formation of Enterobacter aerogenes in mackerel muscle extract. Journal of Food Protection, 56(5), 410- 413.

Manasa, M., Yashoda, K., Sachidananda Swamy, H.C., Vivek, M. N., Ravi Kumar, T. N., \& Prashith Kekuda, T. R. (2013). Antibacterial efficacy of Pimenta dioica (Linn.) Merill and Anacardium occidentale L. against drug resistant urinary tract pathogens. Journal of Applied Pharmaceutical Science, 3(12), 72-74. http://doi.org/ 10.7324/JAPS.2013.31213

Al-Harbi, R., Al-Wegaisi, R., Moharram, F., Shaaban, M., \& El-Rahman, O. A (2017). Antibacterial and anti-hemolytic activity of tannins from Pimenta dioica against methicillin resistant Staphylococcus aureus. Bangladesh Journal of Pharmacology, 12(1), 63-68. http://dx.doi.org/10.3329/bjp.v12i1.29735

Oussalah, M., Caillet, S., Saucier, L., \& Lacroix, M. (2007). Inhibitory effects of selected plant essential oils on the growth of four pathogenic bacteria: E. coli O157:H7, Salmonella Typhimurium, Staphylococcus aureus and Listeria monocytogenes. Food Control, $\quad$ 18(5), $414-420$. https://doi.org/10.1016/j.foodcont.2005.11.009 